\title{
Benthic primary producers are key to sustain the Wadden Sea food web: stable carbon isotope analysis at landscape scale
}

\author{
M. J. A. Christianen, ${ }^{1,6}$ J. J. Middelburg, ${ }^{2}$ S. J. Holthuijsen, ${ }^{3}$ J. Jouta,,${ }^{1,3}$ T. J. Compton, ${ }^{3}$ T. van der Heide, ${ }^{1,4}$ \\ T. Piersma, ${ }^{1,3}$ J. S. Sinninghe Damsté,,${ }^{2,5}$ H. W. van der Veer, ${ }^{3}$ S. Schouten, ${ }^{2,5}$ and H. OlfF ${ }^{1}$ \\ ${ }^{1}$ Groningen Institute for Evolutionary Life Sciences, University of Groningen, P.O. Box 11103, Groningen 9700 CC The Netherlands \\ ${ }^{2}$ Faculty of Geosciences, Department of Earth Sciences, Utrecht University, Utrecht 3508 TA The Netherlands \\ ${ }^{3}$ Department of Coastal Systems, NIOZ Royal Netherlands Institute for Sea Research, \\ Utrecht University, P.O. Box 59, Den Burg 1790 AB The Netherlands \\ ${ }^{4}$ Institute for Wetland and Water Research, Radboud University Nijmegen, Heyendaalseweg 135, Nijmegen 6525 AJ The Netherlands \\ ${ }_{5}^{5}$ Department of Marine Microbiology and Biogeochemistry, NIOZ Royal Netherlands Institute for Sea Research, \\ Utrecht University, P.O. Box 59, Den Burg 1790 AB The Netherlands
}

\begin{abstract}
Coastal food webs can be supported by local benthic or pelagic primary producers and by the import of organic matter. Distinguishing between these energy sources is essential for our understanding of ecosystem functioning. However, the relative contribution of these components to the food web at the landscape scale is often unclear, as many studies lack good taxonomic and spatial resolution across large areas. Here, using stable carbon isotopes, we report on the primary carbon sources for consumers and their spatial variability across one of the world's largest intertidal ecosystems (Dutch Wadden Sea; $1460 \mathrm{~km}^{2}$ intertidal surface area), at an exceptionally high taxonomic (178 species) and spatial resolution $(9,165$ samples from 839 locations). The absence of overlap in $\delta^{13} \mathrm{C}$ values between consumers and terrestrial organic matter suggests that benthic and pelagic producers dominate carbon input into this food web. In combination with the consistent enrichment of benthic primary producers $\left(\delta^{13} \mathrm{C}-16.3 \%\right.$ oo relative to pelagic primary producers $\left(\delta^{13} \mathrm{C}-18.8\right)$ across the landscape, this allowed the use of a two-food-source isotope-mixing model. This spatially resolved modelling revealed that benthic primary producers (microphytobenthos) are the most important energy source for the majority of consumers at higher trophic levels (worms, molluscs, crustaceans, fish, and birds), and thus to the whole food web. In addition, we found large spatial heterogeneity in the $\delta^{13} \mathrm{C}$ values of benthic primary producers $\left(\delta^{13} \mathrm{C}-19.2\right.$ to $-11.5 \%$ ) and primary consumers $\left(\delta^{13} \mathrm{C}-25.5\right.$ to $-9.9 \%$ ), emphasizing the need for spatially explicit sampling of benthic and pelagic primary producers in coastal ecosystems. Our findings have important implications for our understanding of the functioning of ecological networks and for the management of coastal ecosystems.
\end{abstract}

Key words: carbon subsidy; coastal food web; Dutch Wadden Sea; estuary; macrobenthos; stable carbon isotopes; tidal wetland ecosystem.

\section{INTRODUCTION}

The impact of environmental changes (e.g., eutrophication, hypoxia, ocean acidification) on species in ecosystems is often induced from the base of food webs (Paine 1980, Hoegh-Guldberg and Bruno 2010, Middelburg 2014). Food webs of estuarine ecosystems are fueled by a variety of sources. Energy for heterotrophic organisms at higher trophic levels can originate as allochthonous organic matter from land via rivers, or from the sea via tidal currents. Alternatively, energy can be fixed internally by autochthonous pelagic or benthic primary production (Kamermans 1994, Herman et al. 2000) although the contribution of the latter is often

Manuscript received 30 June 2016; revised 2 March 2017; accepted 15 March 2017. Corresponding Editor: Sergio A. Navarrete.

${ }^{6}$ E-mail: marjolijn.christianen@gmail.com undervalued in these systems (Tatara 1981, Barnes and Hughes 1999). In many food webs, the balance between the different energy sources for food webs is likely affected by coastal engineering, bottom disturbance (e.g., dredging, fishing), eutrophication, and land use changes (Tewfik et al. 2005, Howe and Simenstad 2007). Yet, studies quantifying the main energy sources for diverse species of different trophic levels in estuarine food webs across geographic space are rare. Existing studies frequently focus on specific taxonomic groups such as molluscs and worms (Herman et al. 2000), on microbes and microfauna (Middelburg et al. 2000), on phytoplankton and macrozoobenthos, or focus on budget studies of carbon (energy) flow (Kuipers et al. 1981). In addition, despite the increasing evidence of high spatial heterogeneity in coastal ecosystems (Compton et al. 2013), spatial variation in carbon or food sources is generally rarely studied in estuarine intertidal ecosystems, as samples typically cover relatively small areas, and 
results are not reported in a spatially explicit manner (Herman et al. 2000, Middelburg et al. 2000, Catry et al. 2016).

Stable carbon isotope measurements provide an important tool for unravelling the energy transfer and carbon sources in food webs (Middelburg 2014). Primary producers often differ in $\delta^{13} \mathrm{C}$ values due to differences in carbon substrate (atmospheric carbon dioxide or dissolved inorganic carbon) and in carbon isotope fractionation during photosynthesis (Fry 2006). For example, $\mathrm{CO}_{2}$ limitation during carbon fixation across the stagnant boundary layers of benthic algae explains their less negative $\delta^{13} \mathrm{C}$ values compared to pelagic algae (France 1995). Carbon assimilated by higher consumers can be traced back to the basal resource, as the $\delta^{13} \mathrm{C}$ of consumers largely reflects the $\delta^{13} \mathrm{C}$ of primary producers at the base of the food web (De Niro and Epstein 1978, Fry 2006). As carbon isotopic signatures differ between marine benthic primary producers $\left(\delta^{13} \mathrm{C}-13\right.$ to $-18 \%$; Currin et al. 1995 , Stribling and Cornwell 1997, Riera et al. 1999), marine pelagic primary producers (phytoplankton produced locally or imported; $\delta^{13} \mathrm{C}-22$ to $-20 \%$; (Currin et al. 1995, Creach et al. 1997) and terrestrial, riverine, and estuarine carbon sources $\left(\delta^{13} \mathrm{C}<-27 \%\right.$; Middelburg and Herman 2007), they can be used to trace the relative importance of different energy sources for consumers (Herman et al. 2000).

In this study, we investigated what fuels the Wadden Sea food web. We assessed the relative importance of organic carbon derived from pelagic and benthic primary producers and from imported organic matter to animals in the Dutch Wadden Sea food web using stable carbon isotope signatures of species from different trophic levels at the landscape scale. Here we measured the $\delta^{13} \mathrm{C}$ values at a high spatial and taxonomic resolution totaling 9,165 analysed samples, from 178 species that were collected at 839 sampling locations spread across $1,460 \mathrm{~km}^{2}$ of intertidal flat. This study is also societally relevant because of the high natural value of the Wadden Sea ecosystem (Boere and Piersma 2012) that currently faces major impacts of human activities (Wolff 1983, Piersma et al. 2001, Eriksson et al. 2010, Davidson 2014).

\section{Methods}

\section{Study area}

The Wadden Sea is one of the world's largest intertidal ecosystems (Eisma 1976), bordered by 12 major sandy barrier islands that shelter the tidal area against waves generated by northwesterly and northerly winds (Zagwijn 1986). It spans from The Netherlands to Denmark with an overall surface area of approximately $8,000 \mathrm{~km}^{2}$. The Dutch Wadden Sea accounts for $2,500 \mathrm{~km}^{2}$ of which $1,460 \mathrm{~km}^{2}$ consist of intertidal mudflats (de Jonge et al. 1993, Wolff 2000). In its present form, it is relatively young ( 8,000 yr old).

The Wadden Sea is often described as an estuarine environment due to a distinct input of freshwater and sediment directly from the rivers Eems, Weser, Elbe, IJssel (through sluices from Lake IJsselmeer and Lake Lauwersmeer), and indirect fresh water input from the rivers Meuse and Rhine transported along the Dutch North Sea coast. However, unlike many other estuarine and delta systems, local river influence now is only of minor importance relative to sediment supply from the adjacent coastal zone (Arends 1833, Van Straaten and Kunnen 1957). This is likely the result of the closure of the Zuiderzee estuary $\left(3,200 \mathrm{~km}^{2}\right.$, now Lake IJsselmeer) in 1932 and Lauwerszee $\left(91 \mathrm{~km}^{2}\right.$, now Lake Lauwersmeer) in 1969, leaving the small river Ems as the only river with a still open connection to this estuarine ecosystem. In addition, the Wadden Sea has one of the world's most heavily modified coastlines (Wolff 1983, Piersma et al. 2001, Eriksson et al. 2010, Davidson 2014), and borders one of the most intensively used shallow seas worldwide: the North Sea. Despite these impacts, the Wadden Sea offers important ecosystem services: it functions as a nutrient filter (Verwey 1952); supports high biodiversity and fisheries by providing key habitat to approximately 2,700 marine species, including charismatic seals and porpoises (Zijlstra 1972, Kuipers 1977, Strasser 2002, Compton et al. 2013); and it is a key foraging and resting area along the Atlantic flyway for migratory shorebirds (van de Kam et al. 2004, Blew et al. 2005).

\section{Sampling}

Species composition and biomass data were collected during a spatially comprehensive monitoring campaign (Synoptic Intertidal Benthic Survey, SIBES) between June and October of 2008-2012 (Bijleveld et al. 2012, Compton et al. 2013). This sampling program covers the entire intertidal of the Dutch Wadden Sea and consists of gridded samples taken at $500 \mathrm{~m}$ intervals and additional random samples ( 4,500 samples per year). As samples were collected from June to September, sampling was conducted haphazardly in geographic space over these six weeks to ensure that there was no temporal bias in the sampling and thus in our estimates. Depending on the tide, sampling locations were accessed either by foot or from a small boat. Sediment cores $\left(25 \mathrm{~cm}\right.$ depth, core surface of $0.018 \mathrm{~m}^{2}$ ) were sieved on a $1-\mathrm{mm}^{2}$ mesh sieve in the field, after which all organisms remaining on the sieve were stored for later identification, to species level or the finest taxonomic level possible, and for counting in the laboratory at the Netherlands Institute for Sea Research (NIOZ, Texel, The Netherlands). In addition, biomass (ash free dry mass; AFDM) of each individual or of multiple individuals of the same species (for shells $<8 \mathrm{~mm}$ ) was determined. These samples were first dried for $2-3 \mathrm{~d}$ at $60^{\circ} \mathrm{C}$ and then incinerated for $5 \mathrm{~h}$ at $560^{\circ} \mathrm{C}$. Biomass was then estimated by subtracting the dry from the ash mass (Bijleveld et al. 2012, Compton et al. 2013). Species were selected for stable isotope analysis when they accounted for more than $0.1 \%$ of the total average biomass, or when the species occurred (frequency of occurrence) in more than $10 \%$ of the sampled sites. 
To select the most abundant benthic consumer species for the food source contribution (stable carbon isotope) analysis, we calculated the average biomass (g AFDM/ $\mathrm{m}^{2}$ ) and the percentage of sites where a species was observed and ranked species according to these two criteria (Table 1, Appendix S1: Table S1). In total, 35 species were selected that together accounted for $99 \%$ of the total benthic biomass (Table 1).

\section{$\delta^{13}$ C analysis}

For the stable carbon isotope analysis, we randomly collected samples of benthos, macroalgae, seagrasses, and higher consumers across geographic space, while the SIBES survey was conducted, between June and September of 2011-2014 (see Appendix S1: Table S1 for an overview). Depending on the species type and size, in the laboratory we either used the muscle tissue (fish, crustaceans, and bivalves), soft tissue (other invertebrates), blood plasma (birds), or whole organisms (smaller species or individuals) to estimate the isotope ratios. Fresh leaf material from macroalgae and seagrasses was also used as material for this analysis. All material was rinsed with demineralized water, freeze-dried for up to $96 \mathrm{~h}$, ground, and decalcified (by adding $\mathrm{HCl}$ ) if required. For each species, both acidified and nonacidified biomass were analyzed for $\delta^{13} \mathrm{C}$ to determine whether acidification was required. When a significant depletion in $\delta^{13} \mathrm{C}$ was observed between the acidified and non-acidified biomass for a species, its biomass was acidified for all smaller individuals of the whole data set. Homogenized samples $(\sim 0.4-2 \mathrm{mg}$, depending on species) were weighed into tin cups, or when acidified in silver cups, and analysed for stable carbon isotope composition with a Flash 2000 elemental analyzer coupled online with a Delta V Advantage-isotope monitoring mass spectrometer (irmMS, Thermo Scientific, Waltham, Massachusetts, USA). Stable carbon isotope ratios are expressed in the delta $(\delta)$ notation $\left(\delta^{13} \mathrm{C}\right)$ relative to Vienna PDB. Average reproducibility based on replicate measurements was $\sim 0.18 \%$.

To establish benthic and pelagic baselines of $\delta^{13} \mathrm{C}$ values, we used proxies of long-lived primary consumers (explained further in the last section of this paragraph) of which the diet is well known. This method is often used to indirectly characterize baseline resources because it integrates the variation in $\delta^{13} \mathrm{C}$ over time (Cabana and Rasmussen 1996, Vander Zanden et al. 1999, Post 2002, Marty and Planas 2008, Middelburg 2014). By using proxies for benthic and pelagic primary producers, we avoided problems often encountered when establishing $\delta{ }^{13} \mathrm{C}$ baseline values based on direct measurements of small primary producers, for instance, the physical separation of sources, labor-intensive methods (cell-specific or compound specific isotope measurements), and temporal variability caused by high turnover (Middelburg 2014).

As a proxy for pelagic producer $\delta^{13} \mathrm{C}$ values, we used the $\delta^{13} \mathrm{C}$ values of Mytilus edulis (blue mussel, an obligatory suspension feeder). M. edulis was collected from buoys set in deep channels where the input of resuspended material and terrestrial detritus was minimal. To validate this proxy, we sampled suspended particulate organic matter (POM). POM was collected by filtering $5 \mathrm{~L}$ of water (collected from gullies at neap tide) over pre-combusted Whatman $\mathrm{GF} / \mathrm{F}$ glass fiber filters. Filters were dried for $48 \mathrm{~h}$ at $60^{\circ} \mathrm{C}$ before analysis. The $\delta^{13} \mathrm{C}$ values of POM and the blue mussel were similar (average $\delta^{13} \mathrm{C}-18.9 \% \pm 0.1 \%$ and $-18.8 \% \pm 0.1 \%$ $[$ mean $\pm \mathrm{SE}$ ], $P>0.05$ ), supporting the use of blue mussels from buoys as a proxy for pelagic production.

As a proxy for the $\delta^{13} \mathrm{C}$ values of benthic primary producers (also called microphytobenthos: the microscopic photosynthetic organisms living on the sediment surface that mainly consist of diatoms and cyanobacteria), we used the benthic algal consumer Peringia ulvae (mud snail or Laver spire shell, previously named Hydrobia ulvae; López-Figueroa and Niell 1988). Although $P$. ulvae might not exclusively feed on microphytobenthos, prior work has shown that microphytobenthos is a primary food source (Herman et al. 2000). To validate this proxy, we scraped benthic diatoms from the sediment surface at a selection of sites. After migration through a mesh $(100 \mu \mathrm{m})$ into combusted sand, diatoms were collected in filtered seawater and filtered over a Whatman GF/F glass fiber filter (Eaton and Moss 1966) and analyzed for $\delta^{13} \mathrm{C}$. The $P$. ulvae and microphytobenthos $\delta^{13} \mathrm{C}$ values showed large overlap in their frequency distributions, with $P$. ulvae having a narrower range $(-19.2 \%$ to $-11.5 \%$; average $-16.3 \% \pm 0.1 \%$ ) than microphytobenthos $(-21.7$ to $-10.7 \%$, with average of $-15.7 \pm 0.2 \%$ ) (Appendix S1: Fig. S1C), supporting the use of $P$. ulvae as a proxy for benthic production.

\section{Geographical mapping of $\delta^{13} C$ values}

$\delta^{13} \mathrm{C}$ values of benthic primary producers, pelagic primary producers, and three representative consumers were spatially interpolated over the Dutch Wadden Sea using the ordinary kriging function in ArcGIS (version 10.3; ESRI, Redlands, California, USA) based on a spherical semivariogram model. The kriging - output cell size matched the sampling grid $\left(500 \mathrm{~m}\right.$, SIBES), and a $\delta^{13} \mathrm{C}$ value for a cell was obtained using the values of the six closest sampling points for that organism with a maximum range of $5 \mathrm{~km}$. All interpolated maps, except the map of pelagic primary production, were clipped to intertidal areas and to areas with a maximum distance of $5 \mathrm{~km}$ to the nearest sampling location. Sampling locations used for interpolating $\delta^{13} \mathrm{C}$ values of primary producers amounted to 31 locations (111 samples) for pelagic primary producers and 102 locations (135 samples) for benthic primary producers. To illustrate spatial heterogeneity in primary consumers, three consumers (common cockle, Cerastoderma edule; ragworm, Hediste diversicolor, formerly known as Nereis diversicolor; and Baltic tellin, Limecola balthica formerly known as Macoma balthica) 
TABle 1. Contribution of benthic primary production (mean $\pm \mathrm{SE}$ ) to the diet of the 35 most common benthos species of the intertidal flats of the Dutch Wadden Sea.

\begin{tabular}{|c|c|c|c|c|c|c|c|c|}
\hline \multirow[b]{2}{*}{ Group and species } & \multirow[b]{2}{*}{$\begin{array}{c}\text { Benthic } \\
\text { contribution } \\
(\%)\end{array}$} & \multirow[b]{2}{*}{$\begin{array}{c}\text { Biomass } \\
\left(\mathrm{g} / \mathrm{m}^{2}\right)\end{array}$} & \multirow[b]{2}{*}{$\begin{array}{l}\text { Rank by } \\
\text { biomass }\end{array}$} & \multirow[b]{2}{*}{$\begin{array}{c}\text { Sites where } \\
\text { observed }(\%)\end{array}$} & \multirow[b]{2}{*}{$\begin{array}{l}\text { Rank by } \\
\text { sites where } \\
\text { observed }\end{array}$} & \multicolumn{3}{|c|}{$\delta^{13} \mathrm{C}(\%)$} \\
\hline & & & & & & Mean & Minimum & Maximum \\
\hline \multicolumn{9}{|l|}{ Molluscs } \\
\hline $\begin{array}{l}\text { Cerastoderma } \\
\text { edule }\end{array}$ & $<5 \pm 5$ & 5.8 & 1 & 21 & 10 & $-18.6 \pm 1.3$ & -21.9 & -6.5 \\
\hline Mya arenaria & $63 \pm 21$ & 2.7 & 2 & 10 & 17 & $-17.2 \pm 3.5$ & -21.1 & -3.4 \\
\hline Ensis directus & $23 \pm 12$ & 1.7 & 4 & 11 & 16 & $-18.2 \pm 1.5$ & -21.0 & -11.8 \\
\hline Limecola balthica & $>95 \pm 13$ & 0.9 & 8 & 31 & 5 & $-16.0 \pm 1.9$ & -20.9 & -7.9 \\
\hline Crassostrea gigas & $19 \pm 15$ & 0.9 & 9 & 0.4 & 53 & $-17.8 \pm 0.9$ & -20.8 & -16.8 \\
\hline Mytilus edulis & & 0.8 & 10 & 2 & 35 & $-18.8 \pm 0.1$ & -23.5 & -9.0 \\
\hline Peringia ulvae & & 0.5 & 11 & 11 & 14 & $-16.3 \pm 0.1$ & -25.5 & -8.4 \\
\hline Scrobicularia plana & $>95 \pm 46$ & 0.3 & 13 & 4 & 28 & $-15.7 \pm 1.8$ & -19.7 & -11.1 \\
\hline Littorina littorea & $>95 \pm 25$ & 0.1 & 20 & 0.5 & 52 & $-14.2 \pm 1.4$ & -17.1 & -10.6 \\
\hline $\begin{array}{l}\text { Petricola } \\
\quad \text { pholadiformis }\end{array}$ & $58 \pm 54$ & 0.02 & 26 & 0.3 & 57 & $-18.1 \pm 0.6$ & -19.0 & -17.2 \\
\hline Tellina tenuis & $55 \pm 30$ & 0.02 & 27 & 1 & 44 & $-16.5 \pm 1.0$ & -16.5 & -16.5 \\
\hline Abra tenuis & $>95 \pm 30$ & 0.02 & 30 & 2 & 36 & $-13.2 \pm 2.5$ & -16.5 & -6.4 \\
\hline \multicolumn{9}{|l|}{ Annelids } \\
\hline Arenicola marina & $62 \pm 15$ & 2.4 & 3 & 28 & 7 & $-16.3 \pm 1.2$ & -20.7 & -13.3 \\
\hline Lanice conchilega & $<5 \pm 28$ & 1.1 & 5 & 19 & 11 & $-17.9 \pm 1.2$ & -20.3 & -14.9 \\
\hline Scoloplos armiger & $84 \pm 7$ & 0.9 & 6 & 58 & 1 & $-16.4 \pm 1.3$ & -19.5 & -13.2 \\
\hline Hediste diversicolor & $>95 \pm 10$ & 0.9 & 7 & 31 & 6 & $-16.1 \pm 1.7$ & -20.2 & -9.9 \\
\hline Marenzelleria viridis & $<5 \pm 19$ & 0.3 & 12 & 32 & 4 & $-18.1 \pm 1.0$ & -19.5 & -16.0 \\
\hline Alitta virens & $95 \pm 41$ & 0.2 & 15 & 2 & 39 & $-17.6 \pm 0.2$ & -17.7 & -17.5 \\
\hline Nephtys hombergii & $>95 \pm 52$ & 0.2 & 17 & 13 & 13 & $-15.0 \pm 1.0$ & -17.9 & -13.8 \\
\hline Alitta succinea & $>95 \pm 128$ & 0.1 & 18 & 8 & 21 & $-17.2 \pm 1.5$ & -19.2 & -12.7 \\
\hline Capitella capitata & $<5 \pm 18$ & 0.1 & 19 & 38 & 2 & $-17.9 \pm 0.5$ & -18.5 & -17.2 \\
\hline $\begin{array}{l}\text { Heteromastus } \\
\text { filiformis }\end{array}$ & $<5 \pm 8$ & 0.1 & 21 & 22 & 9 & $-17.7 \pm 1.3$ & -19.7 & -14.2 \\
\hline $\begin{array}{l}\text { Eunereis } \\
\quad \text { longissima }\end{array}$ & $63 \pm 45$ & 0.1 & 23 & 2 & 40 & $-16.8 \pm 1.9$ & -18.4 & -13.5 \\
\hline Eteone longa & $>95 \pm 11$ & 0.05 & 24 & 36 & 3 & $-15.6 \pm 1.2$ & -17.8 & -12.6 \\
\hline Pygospio elegans & $62 \pm 35$ & 0.02 & 28 & 10 & 18 & $-16.5 \pm 1.9$ & -18.6 & -13.5 \\
\hline $\begin{array}{l}\text { Aphelochaeta } \\
\text { marioni }\end{array}$ & $27 \pm 12$ & 0.02 & 29 & 9 & 20 & $-17.7 \pm 0.7$ & -18.2 & -16.6 \\
\hline Bylgides sarsi & $>95 \pm 217$ & 0.01 & 32 & 6 & 23 & $-17.1 \pm 1.0$ & -18.5 & -15.4 \\
\hline Phyllodoce mucosa & $72 \pm 17$ & 0.01 & 33 & 11 & 15 & $-18.2 \pm 1.0$ & -18.2 & -18.2 \\
\hline Polydora cornuta & $78 \pm 27$ & 0.01 & 34 & 9 & 19 & $-18.8 \pm 1.0$ & -18.8 & -18.8 \\
\hline Oligochaeta sp. & $74 \pm 42$ & 0.01 & 35 & 5 & 26 & $-14.7 \pm 1.8$ & -18.7 & -13.4 \\
\hline \multicolumn{9}{|l|}{ Crustaceans } \\
\hline Carcinus maenas & $>95 \pm 10$ & 0.3 & 14 & 6 & 22 & $-15.8 \pm 1.2$ & -23.0 & -11.3 \\
\hline Corophium sp. & $<5 \pm 19$ & 0.2 & 16 & 18 & 12 & $-18.0 \pm 2.3$ & -21.5 & -12.9 \\
\hline Urothoe sp. & $>95 \pm 17$ & 0.1 & 22 & 25 & 8 & $-15.9 \pm 1.4$ & -19.0 & -11.3 \\
\hline Crangon crangon & $>95 \pm 18$ & 0.02 & 25 & 5 & 25 & $-15.0 \pm 1.7$ & -23.2 & -11.4 \\
\hline Bathyporeia sp. & $>95 \pm 101$ & 0.01 & 31 & 5 & 24 & $-14.8 \pm 2.7$ & -16.6 & -12.9 \\
\hline
\end{tabular}

Notes: Presented is the average biomass (mean ash-free dry mass $[\mathrm{AFDM}] \pm \mathrm{SE} \mathrm{g} / \mathrm{m}^{2}$ ), and the relative percentages of sites were species were observed for 35 species that together constituted $99.3 \%$ of the total biomass across sampling sites in $2008-2012$ (nr. sites $3465-4375)$. The rank of each species according to biomass and species prevalence is shown in superscript. Average $\delta^{13} \mathrm{C}$ values $( \pm \mathrm{SE})$ and their range are presented. Note that the use of an average $\delta^{13} \mathrm{C}$ value of a species does not translate directly into the amount of contribution by benthic food sources for some species. M. edulis samples here are used as a proxy for mussels sampled from intertidal flats that rely on resuspended benthic primary producers, and $\delta^{13} \mathrm{C}$ values therefore differ from of "pelagic" mussels sampled from buoys, high up in the water column. $P$. ulvae values are used as a proxy for contribution of benthic food sources, no contributions were calculated for proxies. We chose to constrain values between $5 \%$ and $95 \%$ due to the high spatial variability and average extrapolated values.

were selected because of their high biomass (mean of 5.8, 0.9 , and $0.9 \mathrm{~g} \mathrm{AFDM} / \mathrm{m}^{2}$ across years) and high frequency of occurrence $(21 \%, 31 \%, 31 \%)$, their prominent ecological role (Degraer et al. 2008), and their different feeding strategies, i.e., suspension feeder, scavenger, and facultative deposit feeder, respectively. 


\section{Food source estimation}

The relative contribution of benthic and pelagic food sources was estimated for each consumer at each sampled location to account for the spatial variability in $\delta^{13} \mathrm{C}$ of the two food sources. For each coordinate where a consumer was sampled, $\delta^{13} \mathrm{C}$ values were extracted from extrapolated benthic and pelagic primary producer maps using the function "add values to points" in ArcGIS (Fig. 3). As the $\delta^{13} \mathrm{C}$ of organisms reflects the $\delta^{13} \mathrm{C}$ of primary producers at the base of the food web, stable isotope mixing equations can be used to infer the carbon (energy) supply to consumers (Phillips and Gregg 2003, Tewfik et al. 2005). Here, a simple two-end member isotopemixing model was used to calculate the contribution of benthic primary producer carbon ( $\left.f_{\text {benthic primary producers }}\right)$ to each consumer at each sampled location

$$
\begin{aligned}
& f_{\text {benthic primary producers }}(\%) \\
& =\left(\delta^{1} 3 \mathrm{C}_{\text {consumer }}-\delta^{1} 3 \mathrm{C}_{\text {pelagic primary producer }}\right) \\
& \quad /\left(\delta^{1} 3 \mathrm{C}_{\text {benthic primary producers }}-\delta^{1} 3 \mathrm{C}_{\text {pelagic primary producer }}\right) \\
& \quad \times 100
\end{aligned}
$$

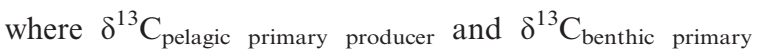
producer are the carbon values of the proxies for primary producers (buoy-attached blue mussel and mud snail, respectively). The resulting values were averaged over all sampling locations, yielding the average contribution of benthic production for all measured members of the Wadden Sea food web (Fig. 1). The rationale for using this two-end-member mixing model is presented later in Results.

Our simple two-end-member approach neglects trophic fractionation and therefore might overestimate the contribution of the ${ }^{13} \mathrm{C}$-rich food sources, i.e., benthic primary producers, with about $10-20 \%$ (see Discussion). The resulting $f_{\text {benthic primary producers }}(\%)$ was spatially extrapolated using the method described above and presented in maps (Figs. 2 and 3). To obtain the most robust estimation of the relative contribution of the two sources in space and to account for the high spatial variability we chose to constrain values of the food source contribution between $5 \%$ and $95 \%$ confidence intervals.

\section{RESULTS}

\section{Benthic species biomass and density}

The selection procedure for the most abundant benthic consumers (see Methods) yielded 35 out of a total of 111 benthic species, which together accounted for $99.3 \%$ of the total benthic intertidal biomass. The mean benthos

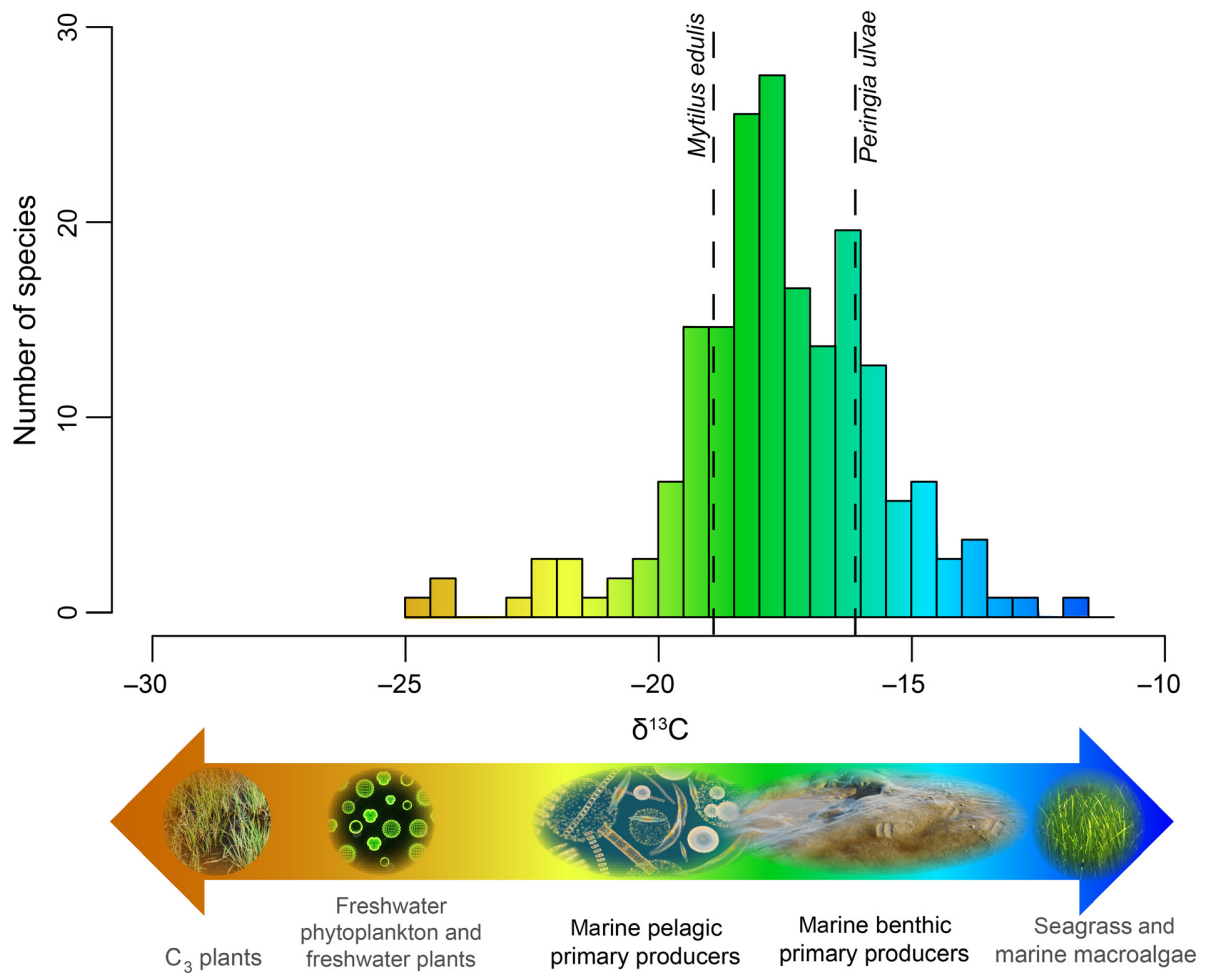

FIG. 1. Frequency distribution of median $\delta^{13} \mathrm{C}$ values of most species of the Dutch Wadden Sea (178 species, 9165 samples) shows that energy for the Wadden Sea ecosystem is mainly provided by locally produced organic matter (benthic primary producers; $\delta^{13} \mathrm{C}$ range, $-19.2 \%$ to $-11.5 \%$ ) and to a lesser extent by pelagic producers $\left(\delta^{13} \mathrm{C}\right.$ range, $-23.3 \%$ to $17.4 \%$ ) and there are no indications for significant external (terrestrial) inputs of organic matter. This graph provides a rationale behind our simple two-food-source mixing model that includes only benthic and pelagic primary producers as a source. Dashed lines show median $\delta^{13} \mathrm{C}$ values of the proxies used to map benthic (Peringia ulvae) and pelagic (Mytilus edulis) producers. [Color figure can be viewed at wileyonlinelibrary.com] 


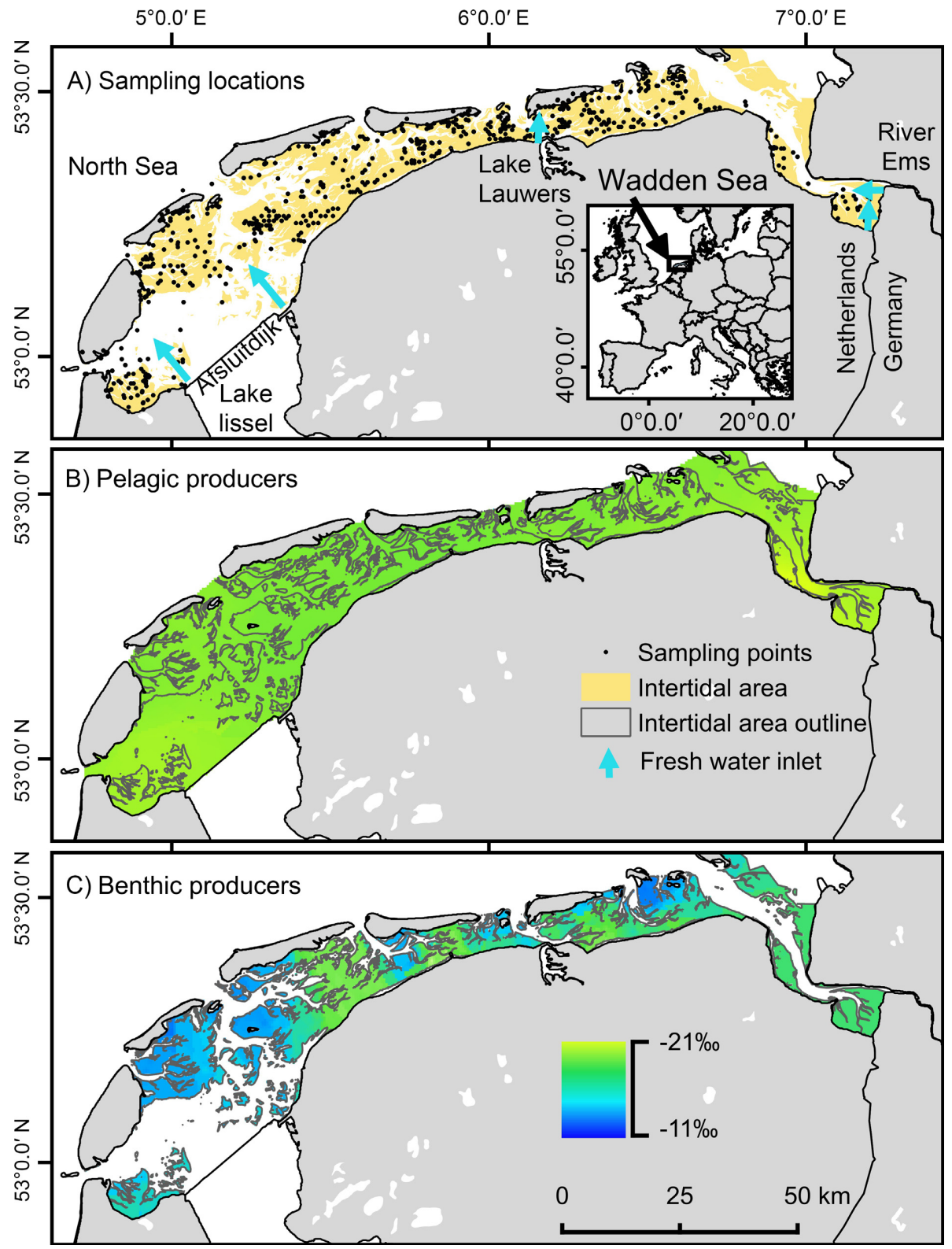

FIG. 2. Map of the Dutch Wadden Sea with (A) sampling locations $(n=839)$ for carbon isotope analysis (black dots, 9165 samples), fresh water inlets (blue arrows) and intertidal areas (orange, $\pm 1,460 \mathrm{~km}^{2}$ ), (B) extrapolated $\delta^{13} \mathrm{C}$ stable isotope values of pelagic primary producers, using pelagic first consumers (Mytilus edulis from buoys) as a proxy, and $(\mathrm{C})$ extrapolated $\delta^{13} \mathrm{C}$ stable isotope values of benthic primary producers using benthic first consumer (Peringia ulvae) as a proxy. Pelagic primary producers show a rather uniform pattern with relatively negative $\delta^{13} \mathrm{C}$ values $\left(\delta^{13} \mathrm{C}\right.$ minimum -23.3 , maximum $\left.\pm-17.4 \%\right)$. Benthic primary producers show a more heterogeneous pattern with less negative $\delta^{13} \mathrm{C}$ values $\left(\delta^{13} \mathrm{C} \min \pm-19.2, \max \pm-11.5 \%\right.$ o $)$. Note that the extent of the geographical mapping of primary producers was adjusted to their habitat; Benthic primary producer $\delta^{13} \mathrm{C}$ values were geographically mapped to the intertidal area and pelagic primary producer $\delta^{13} \mathrm{C}$ values were extrapolated over the whole Dutch Wadden Sea. [Color figure can be viewed at wileyonlinelibrary.com]

biomass across sampling points was on average $25 \mathrm{~g}$ AFDM $\cdot \mathrm{m}^{-2} \cdot \mathrm{yr}^{-1}$ over the sampling period 2008-2012 $(n=3467-4179)$. Species ranking, average biomass, and the frequency of occurrence are presented in Table 1. The three benthic primary consumers contributing the highest mean biomass across the Dutch Wadden Sea were the common cockle (Cerastoderma edule; $5.8 \mathrm{~g} \mathrm{AFDM} / \mathrm{m}^{2}$ ), the soft-shell clam (Mya arenaria; $2.7 \mathrm{~g} \mathrm{AFDM} / \mathrm{m}^{2}$ ), and the lugworm (A. marina: $2.4 \mathrm{~g}$ AFDM $/ \mathrm{m}^{2}$ ).

\section{Validation of two-food-source mixing model}

The frequency distribution of median $\delta^{13} \mathrm{C}$ values of 178 species (Fig. 1) showed that values varied from 


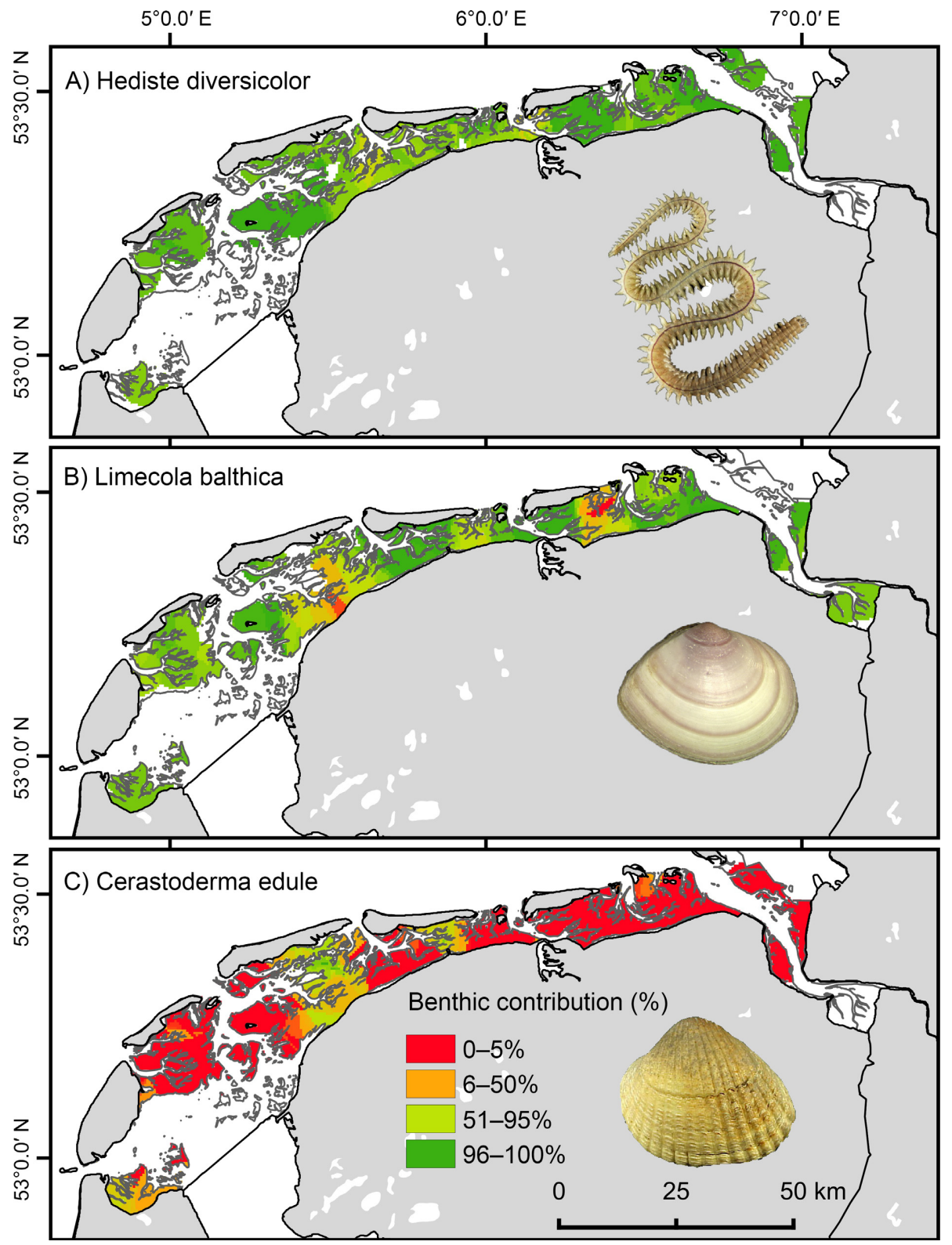

FIG. 3. Relative contribution of benthic primary production for key consumers (A) Hediste diversicolor $(n=120)$, (B) Limecola balthica $(n=139)$, and $(C)$ Cerastoderma edule $(n=346)$ extrapolated over the Dutch Wadden Sea. Green, energy predominantly from benthic primary production; red, energy predominantly from pelagic primary production. [Color figure can be viewed at wileyonlinelibrary.com]

$-25 \%$ to $-11.5 \%$ with $95 \%$ of the values falling between $-20 \%$ and $-14.5 \%$. Thus, the $\delta^{13} \mathrm{C}$ values of almost all consumers in the Wadden Sea food web fall within the range of the proxies for benthic primary producers (mud snail; $\delta^{13} \mathrm{C}$ range $-19.2 \%$ to $-11.5 \% ;-16.3 \% \pm 0.1 \%$ $[$ mean $\pm \mathrm{SE}]$ ) and for pelagic phytoplankton living in the Wadden Sea or imported by tides from the North Sea (buoy-attached blue mussel; $\delta^{13} \mathrm{C}$ range $-23.5 \%$ to $-17.3 \% ;-18.8 \% \pm 0.1 \%$ oo . To test for temporal variability, relations between $\delta^{13} \mathrm{C}$ and time were analysed for some highly dominant species and found to be not significant (e.g., P. ulvae; $R=0.0025$ ). Naturally, this simplification does not exclude contributions of other food sources on a local scale in this highly dynamic system.

\section{Spatial heterogeneity of $\delta^{13} C$ values: primary producers}

The spatial patterns of $\delta^{13} \mathrm{C}$ values of our proxies for benthic (P. ulvae) and pelagic primary producers (M. edulis) were clearly different (Fig. 2) and showed little overlap (Appendix S1: Fig. S1). Isotope data of M. edulis (blue mussels collected from buoys) indicated 
that their $\delta^{13} \mathrm{C}$ values were geographically uniform across the Wadden Sea (averaging $-18.8 \% \pm 0.12 \%$ o $)$. In contrast, benthic primary producers showed a more heterogeneous pattern in space with significantly less negative values of $\delta^{13} \mathrm{C}$ on average $(-16.3 \% \pm 0.12 \%$ o than the primary producers. The difference between $\delta^{13} \mathrm{C}$ values of benthic and pelagic primary producers averaged $2.15 \% \pm 0.11 \%$ (range $0-4.9 \%$ ). Although the average $\delta^{13} \mathrm{C}$ ranges of both primary producers overlapped (Fig. 2), at a landscape scale this overlap in $\delta^{13} \mathrm{C}$ values was absent due to spatial heterogeneity. This suggests that, although the difference in isotopic composition was relatively small, we could distinguish benthic and pelagic energy sources in consumers.

\section{Spatial heterogeneity of $\delta^{13} C$ values: consumers}

The stable carbon isotope values of benthic consumers showed high spatial heterogeneity (e.g., Appendix S1: Fig. S2) for species that either foraged on benthic (Fig. S2A and B) or pelagic resources (Fig. S2C) and these patterns varied between different consumers. To illustrate the different types of spatial patterns in $\delta^{13} \mathrm{C}$ values, we constructed maps of three abundant benthic primary consumers that represent species with three different feeding strategies (Fig. 3). Spatial pattern in the $\delta^{13} \mathrm{C}$ values of the ragworm (Hediste diversicolor), a scavenger, was heterogeneous (Fig. 3A). Stable carbon isotope values of the common cockle, a suspension feeder, reflected the dominance of pelagic primary production over a large part of the Wadden Sea. Only in a small restricted area (high intertidal muddy areas south of Terschelling Island) $\delta^{13} \mathrm{C}$ values reflected dominance of benthic producers $(>50 \%$ benthic contribution; Fig. 3C). The $\delta^{13} \mathrm{C}$ patterns of the Baltic tellin (Limecola balthica; Fig. 3B), a facultative deposit feeder, showed high spatial heterogeneity mainly with values indicating a high benthic contribution to its diet, but in some areas values indicated a high pelagic contribution to the diet as well.

\section{Estimation of food sources}

The results from our spatially resolved, two-food-sources, mixing model showed that benthic primary producers were the dominant food source for $74 \%$ of the 35 most abundant benthic species (Fig. 4). Species that depended predominantly on benthic primary production together accounted for $52 \%$ of total benthic biomass (see Discussion for an explanation on this conservative estimation).

Our spatially resolved, two-food-sources, mixing model was also used to calculate the $\delta^{13} \mathrm{C}$ food source contribution for 143 other, less abundant, species (Appendix S1: Table S1). Benthic primary producers were also important for these less abundant species, and their contribution dominated in 42 species. These 42 species were typically more abundant in benthic samples (e.g., see higher " $n$ " values in Appendix S1: Table S1) compared to species that depended more on pelagic primary production. However, the contribution of the two food sources to the total community carbon flow could not be quantified as biomass data was unavailable for many species of higher trophic levels (e.g., fish).

\section{Discussion}

Thorough quantifications of the main food sources for heterotrophic species at different trophic levels in coastal food webs are rare, but are needed to understand the functioning of food webs. Tidal systems such as the Wadden Sea are home to many benthic and pelagic primary producers and also receive organic matter from adjacent systems such as the North Sea and rivers (Kuipers et al. 1981, van Raaphorst and van der Veer 1990, Bouillon et al. 2011). With our two-food-source mixing model, based on the pelagic and benthic primary producer proxies, the food contribution was resolved for $91 \%$ of the benthic species. Some of the non-resolved species were migrants (e.g., European river lamprey, Lampetra fluviatilis and Brent Goose, Branta bernicla). Others were worms that showed predominant utilization of pelagic carbon sources but actually live buried deep in the mud, out of reach of pelagic sources, and are most likely to feed on bacteria (e.g., spionid polychaete, Marenzelleria viridis; gallery worm, Capitella capitata; red thread worm, Heteromastus filiformis).

Our results showed that benthic primary producers that thrive on the intertidal mudflats (primarily microphytobenthos) supported the majority of consumers in the Wadden Sea food web (Fig. 5). Phytoplanktonic organic matter (POM) had $\delta^{13} \mathrm{C}$ values higher than $-22 \%$ (range $\delta^{13} \mathrm{C}-22.5 \%$ to $-15.7 \%$ ), typical for POM (Middelburg and Herman 2007), but distinctly different from terrestrial, riverine, and estuarine carbon resources (with $\delta^{13} \mathrm{C}$ values typically in the range from $-26 \%$ to $-30 \%$; Middelburg and Herman 2007). This suggests relatively low contributions of terrestrial organic matter, which is therefore unlikely to be a major resource in the Wadden Sea at present. Another potential food source included macrophytes, e.g., seagrasses $\left(\delta^{13} \mathrm{C}\right.$ values ranging between $-15.2 \%$ and $-10.9 \%$; average $-13.0 \% \pm 0.2 \%$ o [mean $\pm \mathrm{SE}]$ ). Although these values potentially overlapped with some of the consumers they are unlikely to contribute significantly to the carbon flow and thus to consumers in the Dutch Wadden Sea, as seagrasses are nearly ecologically extinct in the Dutch Wadden Sea (Folmer et al. 2016) and extensive macroalgae fields are lacking.

Our findings are fully consistent with the results of Herman et al. (2000) and Middelburg et al. (2000). These small-scale studies combined a natural abundance stable isotope approach with an isotope tracer study in the Wester Scheldt estuary and showed that benthic consumers in intertidal ecosystems depend heavily on benthic primary production. However, our results appear inconsistent with traditional diet studies in the Wadden 
Sea area that show that benthic consumers in intertidal ecosystems are primarily dependent on imported organic matter or local primary production in the water column. For example, in the Balgzand area of the Wadden Sea, the stomach contents of intertidal deposit and filter feeders (Cerastoderma edule, Mya arenaria, and Mytilus edulis) suggested a dependence on pelagic algae (Kamermans 1994). Furthermore, studies in the same area suggested that phytoplankton production was the most important component to the organic matter budget (Colijn and de Jonge 1984). At this point, we cannot distinguish whether this discrepancy with previous literature is explained by (1) changes in ecosystem functioning between the 1980s and the present (Philippart et al. 2000, Eriksson et al. 2010, van der Veer et al. 2015), (2) the methods used, or (3) the much more spatially restricted location of the Balgzand studies (Beukema et al. 2002), close to a freshwater outlet, a hypothesis that is supported by the more negative $\delta^{13} \mathrm{C}$ POM values that we found here.

In terms of total available biomass, consumers depending on benthic and pelagic primary producers are similarly dominant in this system (Figs. 4 and 5, Appendix S1: Table S1). However, in terms of harvestable biomass (i.e., the biomass available for species higher up the food chain) benthic primary production is the most dominant food source. Although the common cockle is a pelagic consumer that is important for higher consumers and has a very high biomass $(23 \%$, relative to the total, based on 5-yr monitoring data), its harvestable fraction for consumers can be low. For example, its harvestable fraction for birds like the Red Knot (Calidris
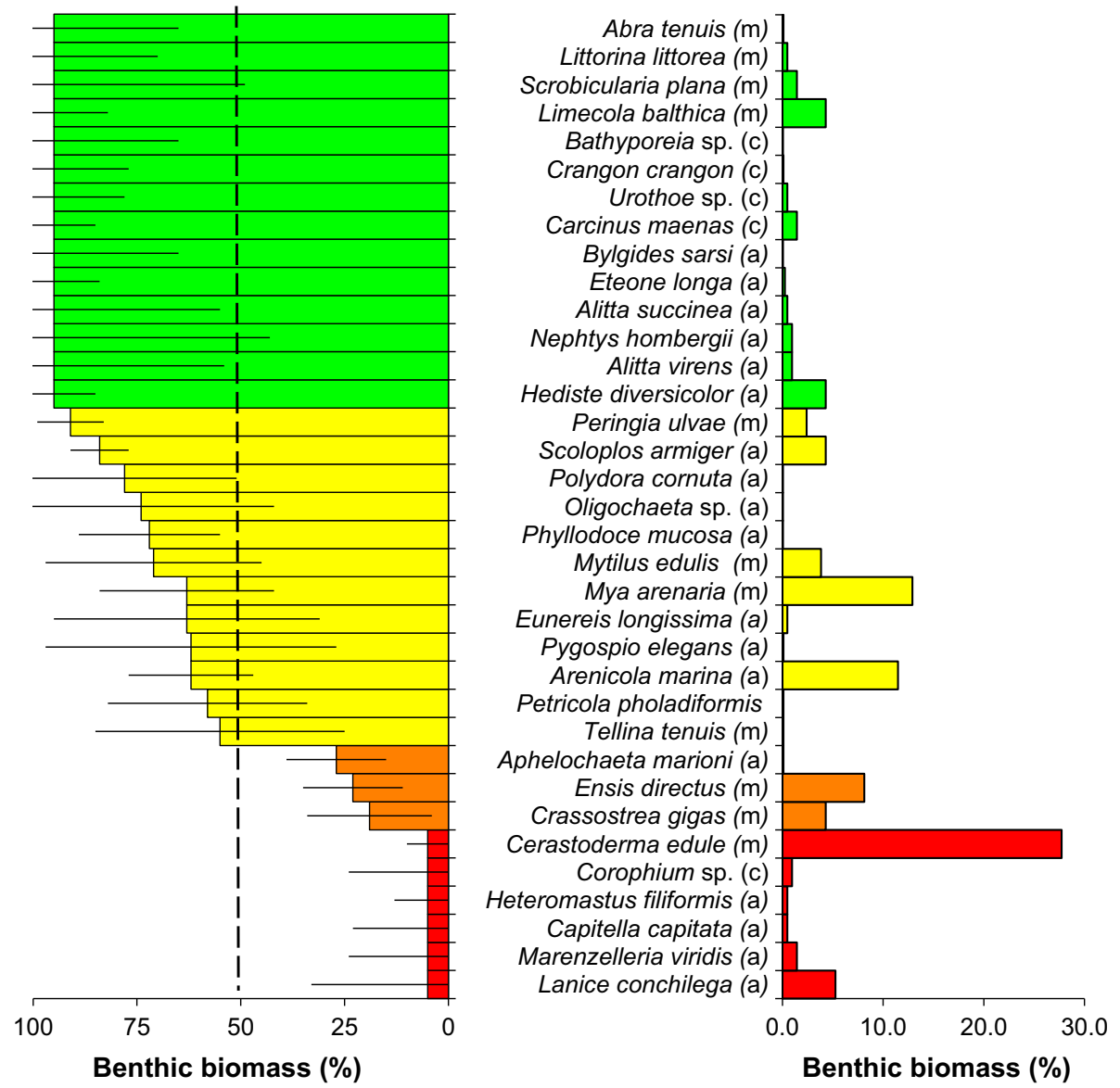

FIG. 4. (A) Contribution of benthic primary production (\%) to the 35 most common benthos species of the intertidal flats of the Dutch Wadden Sea, resulting from the two-food-source mixing model. Presented are values (mean \pm SE) of contribution by benthic food sources averaged across sampling locations in the Dutch Wadden Sea for each species. The species' taxonomic class is presented in brackets; m, molluscs; c, crustacean; a, annelida. M. edulis here represent benthic mussels sampled on intertidal flats that rely on resuspended benthic primary producers, and $\delta^{13} \mathrm{C}$ values therefore differ from the "pelagic" mussels sampled as from buoys as proxies for pelagic producers, high up in the water column. (B) Relative benthic biomass of 35 benthos species. Species that are dependent predominantly $(>50 \%)$ on benthic primary contribution together account for $52 \%$ of total benthic biomass. The percentage of energy from benthic primary production is presented in colors: green: $>95 \%$; yellow, $50-95 \%$; orange, $5-50 \%$; red, $<5 \%$. Note that the value for $M$. edulis is an underestimation due to the fact that the common cockle that represents $23 \%$ of the biomass dependent on pelagic contribution, while in fact only $1 \%$ is harvestable (e.g., by shore birds such as Red Knot that only eat shells $<12 \mathrm{~mm}$ ) and available for higher organisms. [Color figure can be viewed at wileyonlinelibrary.com] 


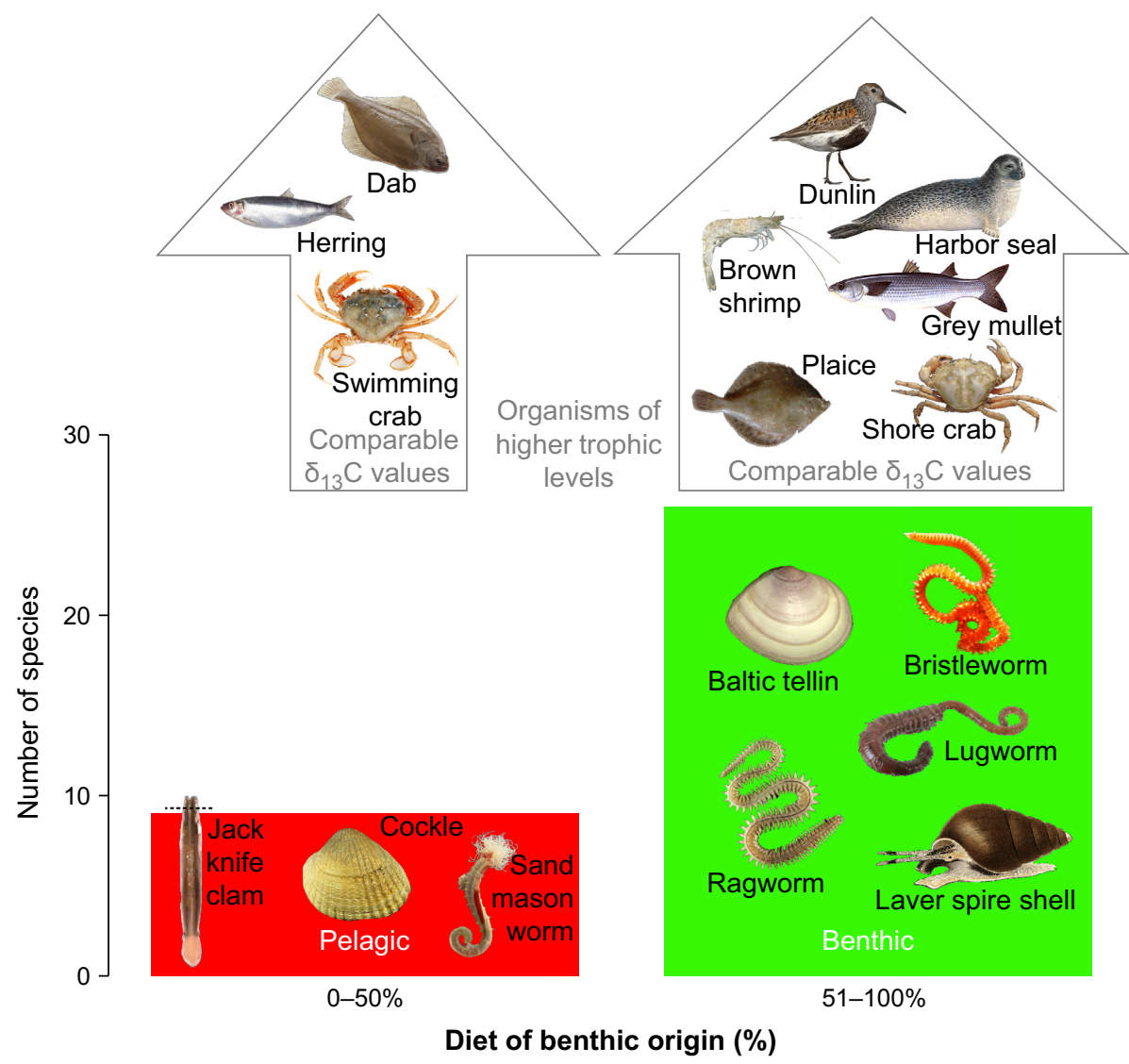

FIG. 5. Conceptual diagram on the importance of benthic production to species higher up the food chain. Relative contribution of benthic primary production (\%) to the diet of the 35 most common benthos species of the intertidal flats of the Dutch Wadden Sea classified into $0-50 \%$ (red) and 51-100\% dependence on benthic algae production (green). Bars include figures of some of the most abundant species of each two classes. Examples of species of higher trophic levels with "benthic" or "pelagic" of "intermediate" $\delta{ }^{13} \mathrm{C}$ signals are presented inside arrows (see Appendix S1: Table S1 for details). [Color figure can be viewed at wileyonlinelibrary.com]

canutus) only equates to $1 \%$ of the total available biomass, as it depends on the size of the bill (Zwarts et al. 1992, Bijleveld et al. 2015). Examples of consumers that depend on benthic production and might also exhibit size selectivity include Limosa lapponica (Duijns et al. 2013) and Pluvialis squatarola (Kersten and Piersma 1984), Calidris alpina (feeding on Scoloplos armiger personal observation T. Piersma). Correcting biomass contributions for other species would likely further increase the proportion of benthic carbon contribution. On the one hand, our estimation of the contribution of benthic food sources in our study may be conservative because a small contribution of terrestrial, riverine, and estuarine carbon resources to food resources (with more negative $\delta^{13} \mathrm{C}$ values like in the Ems estuary) would increase the percentage of pelagic contribution in our two-foodsource mixing model and underestimate the contribution of benthic sources (with more positive $\delta^{13} \mathrm{C}$ values compared to pelagic sources). On the other hand, the contribution of benthic food source may be slightly overestimated (10-20\%) for higher trophic levels if carbon is enriched per trophic transfer.

\section{Dominance of benthic food sources in} coastal systems - Is it a common phenomenon?

To explore if the dominance of benthic food sources is a general phenomenon in coastal ecosystems worldwide, we compared $\delta^{13} \mathrm{C}$ of producers and consumers in other coastal systems from data in the literature. In the Westerschelde (The Netherlands), $95 \%$ of the benthic macrobenthos (Herman et al. 2000), as well as bacteria and meiobenthos (Middelburg et al. 2000) were found to depend on benthic primary production. In the Seto Inland Sea (Japan), 92\% of demersal fish species showed $\delta^{13} \mathrm{C}$ values between $-17 \%$ and $-13 \%$, likely indicating a high contribution of benthic primary producers to consumers at the top of food webs (Takai et al. 2002). This is further supported by a review on saltmarsh food webs throughout the East and Gulf Coasts of North America that found average $\delta^{13} \mathrm{C}$ values between $-16.3 \%$ and $-13.9 \%$ for macrofauna species, similar to an average $\delta^{13} \mathrm{C}$ value for benthic primary producers of $-15.5 \%$ o (Currin et al. 1995). Benthic primary production was also found to be dominant in salt marsh consumers in Mont 
St. Michel, France (Creach et al. 1997), saltmarsh mudflat infauna at Plum Island Estuary, USA (Galvan et al. 2008), and the Pearl River estuary, China (Lee 2000), for cockles in Marennes-Oleron Bay, France (Kang et al. 1999) and for prawns in Klang river creeks, Malaysia (Newell et al. 1995). Even in deeper coastal areas, the carbon subsidy of benthic food sources might still be high, as studies in the South Atlantic Bight (USA) found that microphytobenthos contributed $40 \%$ to the system's primary production at depths of 14-40 m (Jahnke et al. 2000). Although most of these studies only focused on a few species, typically covered small areas, and had a limited sample size, they seem to suggest that a dominance of benthic food sources is the rule rather than the exception in the deltas of this world.

Together the dominance of consumers' $\delta^{13} \mathrm{C}$ values between those of the mud snail and buoy-attached blue mussel, and the lack of substantial terrestrial, riverine, and macrophyte carbon resources suggested that a simple two-food-source mixing model could be applied to determine the major sources of food for animals higher up the food web. Our assumption is supported by isotope studies on other intertidal areas that have also found that the main higher trophic levels fed very selectively and relied primarily on microphytobenthos and pelagic primary production (van Oevelen et al. 2006). Naturally, this simplification does not exclude contributions of other food sources on a local scale in this highly dynamic system. The absolute distinction between pelagic and benthic algae in shallow, tidal systems is not straightforward because phytoplankton represent a dynamic mixture of benthic and pelagic algae due to intensive tidally driven resuspension-deposition cycles (Herman et al. 1999, Lucas et al. 2001). Stable isotope analysis provides information on the locus of carbon fixation (pelagic vs. benthic) and thus on the eventual energy source and not so much on where the carbon has been consumed. For instance, resuspended benthic algae consumed by suspension feeders will be recorded as a benthic contribution by stable isotope analysis. Stable isotope analysis integrates the assimilated diet across time and unlike stomach analysis is able to bypass the source determination of mixed particles in degraded forms (De Niro and Epstein 1978, Fry 2006).

\section{Spatial patterning in carbon isotope values: Implications for understanding of marine food webs}

Our high-resolution study enabled a detailed evaluation of spatial heterogeneity in the isotopic composition of food sources of benthic consumers in a coastal region and is among the most extensive stable isotope food web studies ever attempted. We found a remarkable degree of spatial heterogeneity, of especially benthic primary producer carbon isotope values, throughout our study area at scales larger than the patchy occurrence of the individual benthic species (Kraan et al. 2009). The cause for this large spatial variability is unclear. We found a positive correlation between benthic primary producer $\delta^{13} \mathrm{C}$ values and the exposure time (hours without inundation) of each sampled location $\left(R^{2}=0.55\right.$, Appendix S1: Fig. S3; i.e., less negative values with increased exposure to air) as measured from tidal elevation. This indicates that benthic producers on longer exposed areas have different $\delta^{13} \mathrm{C}$ values than those in areas that are more frequently flooded or permanently submerged. Possibly different diatom species could dominate in different depth zones, and also explain some of the spatial variability (Henley et al. 2012). As thicker stagnant boundary layers around benthic algae increase diffusion limitation of $\mathrm{CO}_{2}$ and consequently decrease overall fractionation (France 1995, Hopkinson et al. 2011), this could result in more positive $\delta^{13} \mathrm{C}$ values in areas of lower flow velocities. Reduced water depth might also yield more positive $\delta^{13} \mathrm{C}$ values, as benthic algae living higher on intertidal mudflats are more productive, which generally results in decreased isotopic fractionation (Laws et al. 1995). Regardless of the exact cause, it is clear that benthic primary producers show an isotopic variability that is strongly influenced by geophysical, and therefore spatial factors.

\section{Spatial patterning in carbon isotope values: Implications for food web sampling and modelling}

Our study has important implications for future food web studies. Spatial heterogeneity in $\delta^{13} \mathrm{C}$ values of primary producers has been reported for seagrasses (Fourqurean et al. 1997), phytoplankton (Boschker et al. 2005, Tamelander et al. 2009), coastal kelp (Simenstad et al. 1993), and salt marshes (Deegan and Garritt 1997), but has yet to be studied for benthic microalgae in marine environments. Our data showed that stable carbon isotopes of benthic primary producers are location dependent. Consequently, modelling of reliable future food web studies should be adjusted and incorporate high-resolution spatial sampling of benthic primary producers, and not use extrapolations based on a limited number and/or local measurements. The relatively homogeneous stable carbon isotope pattern of cockles (Fig. 2B), as determined here for the Wadden Sea, indicates that isotope food-web modelling for pelagic producers may perhaps be done using one single endmember that is independent of location. However, as this outcome may be specific for the Wadden Sea, we also recommend a high-resolution spatial sampling scheme for pelagic primary producers using proxies that are simple to collect. Specifically, environmental monitoring programs (Parr et al. 2003) need to include spatially explicit sampling of benthic and pelagic primary producers in coastal systems to improve our current understanding of food web functioning.

Consumer carbon isotope values also showed spatial heterogeneity, however, patterns and mechanisms differed between consumers. For example, the polychaete Hediste diversicolor is predominantly dependent on benthic 
primary production (Fig. 3A) even though the species is known to be a scavenger that adapts its diet to food availability including phytoplankton, zooplankton, and bacteria (Costa et al. 2006). The bivalve Limecola balthica showed differential pelagic-benthic consumption with a high pelagic contribution in some areas of the Wadden Sea (Fig. 3B). This facultative deposit feeding bivalve (de Goeij et al. 2001) lives buried in the mud and uses its siphon to feed on organic matter from the sediment surface (greenish areas; Fig. 3B) or in the water (more reddish areas; Fig. 3B). Spatial heterogeneity patterns in L. balthica could not be explained by ontogenetic shifts toward more suspension feeding in larger individuals (Rossi et al. 2004) $\left(R^{2}=0.001\right.$, Appendix S1: Fig. S3). The bivalve Cerastoderma edule is an obligatory suspension feeder (Kamermans 1994) comparable to the mussels collected from buoys in deeper water. Specifically, it feeds much closer to the sediment-water interface and thus, although pelagic primary production dominated the $\delta^{13} \mathrm{C}$ values in this species (Fig. 3C), this species also incorporated resuspended benthic algae.

The different spatial patterning observed for the different benthic consumers likely results from various factors: (1) spatial variability in benthic production, (2) differential consumption of benthic and pelagic producers, and/or (3) the differential contribution of resuspended benthic primary producers for consumers feeding entirely on pelagic producers. The spatial heterogeneity at multiple trophic levels emphasizes the necessity of location dependent food-web modelling over large spatial scales. For many species of higher trophic levels, food source contribution estimates have to be interpreted with care and more advanced extrapolation techniques may have to be developed to cope with the low spatial sampling resolution of some species and the considerable movement range of individuals.

\section{Implications for nature conservation}

The observation that a substantial portion of the food web depends on local benthic primary production in the Dutch Wadden Sea implies that human and naturally induced disturbance of mudflats, and its benthic diatoms, could have cascading effects further up the food web. Current human activities in the Wadden Sea, such as bottom trawling for shrimp, sand supplementation to reduce coastal erosion, drilling for gas, dredging for shells (including the hand-dredging for cockles), and dredging of shipping routes, all potentially affect benthic productivity, as they modify light availability, sediment grain size, air exposure time, surface area available for benthic primary producers, and depth of tidal areas, or destroy diatom mats (Beukema 1995, Piersma et al. 2001, Erftemeijer and Lewis 2006, Eriksson et al. 2010, Mercado-Allen and Goldberg 2011, Compton et al. 2016). Our study underlines the pivotal role of benthic primary producers in this ecosystem and thus the pressing need to preserve and protect these pillars of the food web and the intertidal flats on which they grow. The further inclusion of food web studies and basic food web metrics (Christianen et al. 2016) can support monitoring and management of these ecosystems.

\section{ACKNOWLEDGMENTS}

For sampling the food web, we thank the SIBES program; volunteers, staff, and students, and the crew of $R V$ Navicula; the volunteers of Natuurmonumenten; the volunteers of Staatsbosbeheer; Zwannette Jager (Eemscentrale power plant) for fish samples; Sophie Brasseur (IMARES) for samples of harbour seals; Mardik Leopold (IMARES) for samples of harbour porpoise; Wimke Fokkema (RUG) for Brent Geese samples; Josje Fens (Waddenvereniging) for seagrass samples. We thank Kevin Donkers and Thomas Leerink (NIOZ) for technical assistance in stable isotope analyses. This study was carried out as part of the project "Waddensleutels" funded by "Waddenfonds" (WF203930). Wilfred Alblas, Quirin Smeele, (both Natuurmonumenten) and Michel Firet (Staatsbosbeheer) played an important role in guarding the progress and links to nature conservation of the Waddensleutels project. SIBES-monitoring was financially supported by NAM, NWO-ALW (ZKO program) and Royal NIOZ. T. Piersma was supported by Waddenfonds project "Metawad" (WF209925), M. J. A. Christianen was also supported by NWO-ALW (Caribbean program 858.14092).

\section{Literature Cited}

Arends, J. R. L. 1833. Physische Geschichte der Nordsee- Küste und deren Veranderungen durch Sturmfluthen seit der Cymbrischen Fluth bis jetzt. Facsimile print 1974, Verlag Schuster, Leer, Germany.

Barnes, R. S. K., and R. N. Hughes. 1999. An introduction to marine ecology. John Wiley \& Sons, New York, New York, USA.

Beukema, J. 1995. Long-term effects of mechanical harvesting of lugworms Arenicola marina on the zoobenthic community of a tidal flat in the Wadden Sea. Netherlands Journal of Sea Research 33:219-227.

Beukema, J. J., G. C. Cadee, and R. Dekker. 2002. Zoobenthic biomass limited by phytoplankton abundance: evidence from parallel changes in two long-term data series in, the Wadden Sea. Journal of Sea Research 48:111-125.

Bijleveld, A. I., J. A. van Gils, J. van der Meer, A. Dekinga, C. Kraan, H. W. van der Veer, and T. Piersma. 2012. Designing a benthic monitoring programme with multiple conflicting objectives. Methods in Ecology and Evolution 3:526-536.

Bijleveld, A. I., S. Twietmeyer, J. Piechocki, J. A. van Gils, and T. Piersma. 2015. Natural selection by pulsed predation: survival of the thickest. Ecology 96:1943-1956.

Blew, J., K. Günther, K. Laursen, M. van Roomen, P. Südbeck, K. Eskildsen, P. R. Potel, and H. Sner. 2005. Overview of numbers and trends of migratory waterbirds in the Wadden Sea 1980-2000. Wadden Sea Ecosystem 20:8-148.

Boere, G. C., and T. Piersma. 2012. Flyway protection and the predicament of our migrant birds: A critical look at international conservation policies and the Dutch Wadden Sea. Ocean and Coastal Management 68:157-168.

Boschker, H. T. S., J. C. Kromkamp, and J. J. Middelburg. 2005. Biomarker and carbon isotopic constraints on bacterial and algal community structure and functioning in a turbid, tidal estuary. Limnology and Oceanography 50:70-80.

Bouillon, S., R. M. Connolly, and D. P. Gillian. 2011. Use of Stable Isotopes to Understand Food Webs and Ecosystem Functioning in Estuaries. Pages 143-173 in E. Polanski, and 
D. S. McLusky, editors. Treatise on estuarine and coastal science. Academic Press, Waltham, Massachusetts, USA.

Cabana, G., and J. B. Rasmussen. 1996. Comparison of aquatic food chains using nitrogen isotopes. Proceedings of the National Academy of Sciences USA 93:10844-10847.

Catry, T., P. M. Lourenco, R. J. Lopes, C. Carneiro, J. A. Alves, J. Costa, H. Rguibi-Idrissi, S. Bearhop, T. Piersma, and J. P. Granadeiro. 2016. Structure and functioning of intertidal food webs along an avian flyway: a comparative approach using stable isotopes. Functional Ecology 30:468-478.

Christianen, M. J. A., T. van der Heide, S. J. Holthuijsen, K. J. van der Reijden, A. C. W. Borst, and H. Olff. 2016. Biodiversity and food web indicators of community recovery in intertidal shellfish reefs. Biological Conservation. https:// doi.org/10.1016/j.biocon.2016.09.028

Colijn, F., and V. N. de Jonge. 1984. Primary production of microphytobenthos in the Ems-Dollard estuary. Marine Ecology Progress Series 14:185-196.

Compton, T. J., et al. 2013. Distinctly variable mudscapes: Distribution gradients of intertidal macrofauna across the Dutch Wadden Sea. Journal of Sea Research 82:103-116.

Compton, T., W. Bodnar, A. Koolhaas, A. Dekinga, S. Holthuijsen, J. ten Horn, N. McSweeney, J. van Gils, and T. Piersma. 2016. Burrowing behavior of a deposit feeding bivalve predicts change in intertidal ecosystem state. Frontiers in Ecology and Evolution 4:19.

Costa, P. F. E., R. F. Oliveira, and L. Cancela da Fonseca. 2006. Feeding ecology of Nereis diversicolor (O.F. Müller) (Annelida, Polychaeta) on estuarine and lagoon environments in the southwest coast of Portugal. Pan-American Journal of Aquatic Sciences 1:114-126.

Creach, V., M. T. Schricke, G. Bertru, and A. Mariotti. 1997. Stable isotopes and gut analyses to determine feeding relationships in saltmarsh macroconsumers. Estuarine Coastal and Shelf Science 44:599-611.

Currin, C. A., S. Y. Newell, and H. W. Paerl. 1995. The role of standing dead Spartina alterniflora and benthic microalgae in salt-marsh food webs - considerations based on multiple stableisotope analysis. Marine Ecology Progress Series 121:99-116.

Davidson, N. C. 2014. How much wetland has the world lost? Long-term and recent trends in global wetland area. Marine and Freshwater Research 65:934-941.

de Goeij, P., P. C. Luttikhuizen, J. van der Meer, and T. Piersma. 2001. Facilitation on an intertidal mudflat: the effect of siphon nipping by flatfish on burying depth of the bivalve Macoma balthica. Oecologia 126:500-506.

de Jonge, V. N., K. Esselink, and R. Boddeke. 1993. The Dutch Wadden Sea: a changed ecosystem. In Netherlands-Wetlands. 45-71. Springer, Netherlands.

De Niro, M. J., and S. Epstein. 1978. Influence of diet on the distribution of carbon isotopes in animals. Geochimica et Cosmochimica Acta 42:495-506.

Deegan, L. A., and R. H. Garritt. 1997. Evidence for spatial variability in estuarine food webs. Marine Ecology Progress Series 147:31-47.

Degraer, S., E. Verfaillie, W. Willems, E. Adriaens, M. Vincx, and V. Van Lancker. 2008. Habitat suitability modelling as a mapping tool for macrobenthic communities: An example from the Belgian part of the North Sea. Continental Shelf Research 28:369-379.

Duijns, S., N. A. Hidayati, and T. Piersma. 2013. Bar-tailed Godwits Limosa 1. lapponica eat polychaete worms wherever they winter in Europe. Bird Study 60:509-517.

Eaton, J. W., and B. Moss. 1966. Estimation of numbers and pigment content in epipelic algal populations. Limnology and Oceanography 11:584-595.
Eisma, D., W. Mook, and H. Das. 1976. Shell characteristics, isotopic composition and trace-element contents of some euryhaline molluscs as indicators of salinity. Palaeogeography, Palaeoclimatology 19:39-62.

Erftemeijer, P. L. A., and R. R. R. Lewis. 2006. Environmental impacts of dredging on seagrasses: a review. Marine Pollution Bulletin 52:1553-1572.

Eriksson, B. K., T. van der Heide, J. van de Koppel, T. Piersma, H. W. van der Veer, and H. Olff. 2010. Major changes in the ecology of the Wadden Sea: human impacts, ecosystem engineering and sediment dynamics. Ecosystems 13:752-764.

Folmer, E. O., J. E. E. van Beusekom, T. Dolch, U. Gräwe, M. M. Katwijk, K. Kolbe, and C. J. M. Philippart. 2016. Consensus forecasting of intertidal seagrass habitat in the Wadden Sea. Journal of Applied Ecology 53:1800-1813.

Fourqurean, J. W., T. O. Moore, B. Fry, and J. T. Hollibaugh. 1997. Spatial and temporal variation in C:N: P ratios, delta $\mathrm{N}-15$ and delta C-13 of eelgrass Zostera marina as indicators of ecosystem processes, Tomales Bay, California, USA. Marine Ecology Progress Series 157:147-157.

France, R. 1995. Carbon-13 enrichment in benthic compared to planktonic algae: foodweb implications. Marine Ecology Progress Series 124:307-312.

Fry, B. 2006. Stable isotope ecology. Springer-Verlag, New York, New York, USA.

Galvan, K., J. W. Fleeger, and B. Fry. 2008. Stable isotope addition reveals dietary importance of phytoplankton and microphytobenthos to saltmarsh infauna. Marine Ecology Progress Series 359:37-49.

Henley, S. F., A. L. Annett, R. S. Ganeshram, D. S. Carson, K. Weston, X. Crosta, A. Tait, J. Dougans, A. E. Fallick, and A. Clarke. 2012. Factors influencing the stable carbon isotopic composition of suspended and sinking organic matter in the coastal Antarctic sea ice environment. Biogeosciences 9:1137-1157.

Herman, P. M. J., J. J. Middelburg, J. Van de Koppel, and C. H. R. Heip. 1999. Ecology of estuarine macrobenthos. Advances in Ecological Research 29:195-240.

Herman, P. M. J., J. J. Middelburg, J. Widdows, C. H. Lucas, and C. H. R. Heip. 2000. Stable isotopes' as trophic tracers: combining field sampling and manipulative labelling of food resources for macrobenthos. Marine Ecology Progress Series 204:79-92.

Hoegh-Guldberg, O., and J. F. Bruno. 2010. The impact of climate change on the world's marine ecosystems. Science 328:1523-1528.

Hopkinson, B. M., C. L. Dupont, A. E. Allen, and F. M. M. Morel. 2011. Efficiency of the CO2-concentrating mechanism of diatoms. Proceedings of the National Academy of Sciences USA 108:3830-3837.

Howe, E. R., and C. A. Simenstad. 2007. Restoration trajectories and food web linkages in San Francisco Bay's estuarine marshes: a manipulative translocation experiment. Marine Ecology Progress Series 351:65-76.

Jahnke, R. A., J. R. Nelson, R. L. Marinelli, and J. E. Eckman. 2000. Benthic flux of biogenic elements on the Southeastern US continental shelf: influence of pore water advective transport and benthic microalgae. Continental Shelf Research 20:109-127.

Kang, C. K., P. G. Sauriau, P. Richard, and G. F. Blanchard. 1999. Food sources of the infaunal suspension-feeding bivalve Cerastoderma edule in a muddy sandflat of MarennesOlÕron Bay, as determined by analyses of carbon and nitrogen stable isotopes. Marine Ecology Progress Series 187: $147-158$. 
Kamermans, P. 1994. Similarity in food source and timing of feeding in deposit-and suspension-feeding bivalves. Marine Ecology Progress Series 104:63-75.

Kersten, M., and T. Piersma. 1984. Voedselkeuze en voedselopname van Zilverplevieren Pluvialis squatarola in de Waddenzee tijdens de voor-en najaarstrek. Limosa 57:105-111.

Kraan, C., J. A. van Gils, B. Spaans, A. Dekinga, A. I. Bijleveld, M. van Roomen, R. Kleefstra, and T. Piersma. 2009. Landscape-scale experiment demonstrates that Wadden Sea intertidal flats are used to capacity by molluscivore migrant shorebirds. Journal of Animal Ecology 78:1259-1268.

Kuipers, B. R. 1977. On the ecology of juvenile plaice on a tidal flat in the Wadden Sea. Journal of Sea Research 11:56-91.

Kuipers, B., P. DeWilde, and F. Creutzberg. 1981. Energy flow in a tidal flat ecosystem. Marine Ecology 5:215-221.

Laws, E. A., B. N. Popp, R. R. Bidigare, M. C. Kennicutt, and S. A. Macko. 1995. Dependence of phytoplankton carbon isotopic composition on growth-rate and $\mathrm{CO} 2$ (aq) - theoretical considerations and experimental results. Geochimica Et Cosmochimica Acta 59:1131-1138.

Lee, S. Y. 2000. Carbon dynamics of Deep Bay, eastern Pearl River estuary, China. II: trophic relationship based on carbon- and nitrogen-stable isotopes. Marine Ecology Progress Series 205:1-10.

López-Figueroa, F., and F. X. Niell. 1988. Feeding behaviour of Hydrobia ulvae (Pennant) in microcosms. Journal of Experimental Marine Biology and Ecology 114:153-167.

Lucas, C. H., C. Banham, and P. M. Holligan. 2001. Benthicpelagic exchange of microalgae at a tidal flat. 2. Taxonomic analysis. Marine Ecology Progress Series 212:39-52.

Marty, J., and D. Planas. 2008. Comparison of methods to determine algal delta C-13 in freshwater. Limnology and Oceanography-Methods 6:51-63.

Mercado-Allen, R., and R. Goldberg. 2011. Review of the ecological effects of dredging in the cultivation and harvest of molluscan shellfish. U.S. Department of Commerce, Milford, Massachusetts, USA.

Middelburg, J. J. 2014. Stable isotopes dissect aquatic food webs from the top to the bottom. Biogeosciences 11:2357-2371.

Middelburg, J. J., and P. M. J. Herman. 2007. Organic matter processing in tidal estuaries. Marine Chemistry 106:127-147.

Middelburg, J. J., C. Barranguet, H. T. S. Boschker, P. M. J. Herman, T. Moens, and C. H. R. Heip. 2000. The fate of intertidal microphytobenthos carbon: an in situ C-13-labeling study. Limnology and Oceanography 45:1224-1234.

Newell, R. I. E., N. Marshall, A. Sasekumar, and V. C. Chong. 1995. Relative importance of benthic microalgae, phytoplankton, and mangroves as sources of nutrition for penaeid prawns and other coastal invertebrates from Malaysia. Marine Biology 123:595-606.

Paine, R. T. 1980. Food webs-linkage, interaction strength and community infrastructure - The 3rd Tensely lecture. Journal of Animal Ecology 49:667-685.

Parr, T. W., A. R. J. Sier, R. W. Battarbee, A. Mackay, and J. Burgess. 2003. Detecting environmental change: science and society - perspectives on long-term research and monitoring in the 21st century. Science of the Total Environment 310:1-8.

Philippart, C. J. M., G. C. Cadee, W. van Raaphorst, and R. Riegman. 2000. Long-term phytoplankton-nutrient interactions in a shallow coastal sea: Algal community structure, nutrient budgets, and denitrification potential. Limnology and Oceanography 45:131-144.

Phillips, D. L., and J. W. Gregg. 2003. Source partitioning using stable isotopes: coping with too many sources. Oecologia 136:261-269.

Piersma, T., A. Koolhaas, A. Dekinga, J. J. Beukema, R. Dekker, and K. Essink. 2001. Long-term indirect effects of mechanical cockle-dredging on intertidal bivalve stocks in the Wadden Sea. Journal of Applied Ecology 38:976-990.

Post, D. M. 2002. Using stable isotopes to estimate trophic position: models, methods, and assumptions. Ecology 83: 703-718.

Riera, P., L. J. Stal, J. Nieuwenhuize, P. Richard, G. Blanchard, and F. Gentil. 1999. Determination of food sources for benthic invertebrates in a salt marsh (Aiguillon Bay, France) by carbon and nitrogen stable isotopes: importance of locally produced sources. Marine Ecology Progress Series 187: 301-307.

Rossi, F., P. M. J. Herman, and J. J. Middelburg. 2004. Interspecific and intraspecific variation of delta C-13 and delta $\mathrm{N}-15$ in deposit- and suspension-feeding bivalves (Macoma balthica and Cerastoderma edule): Evidence of ontogenetic changes in feeding mode of Macoma balthica. Limnology and Oceanography 49:408-414.

Simenstad, C. A., D. O. Duggins, and P. D. Quay. 1993. High turnover of inorganic carbon in kelp habitats as a cause of delta-c-13 variability in marine food webs. Marine Biology 116:147-160.

Strasser, M. 2002. Reduced epibenthic predation on intertidal bivalves after a severe winter in the European Wadden Sea. Marine Ecology Progress Series 241:113-123.

Stribling, J. M., and J. C. Cornwell. 1997. Identification of important primary producers in a Chesapeake Bay tidal creek system using stable isotopes of carbon and sulfur. Estuaries 20:77-85.

Takai, N., Y. Mishima, A. Yorozu, and A. Hoshika. 2002. Carbon sources for demersal fish in the western Seto Inland Sea, Japan, examined by delta C-13 and delta N-15 analyses. Limnology and Oceanography 47:730-741.

Tamelander, T., C. Kivimae, R. G. J. Bellerby, P. E. Renaud, and S. Kristiansen. 2009. Base-line variations in stable isotope values in an Arctic marine ecosystem: effects of carbon and nitrogen uptake by phytoplankton. Hydrobiologia 630:63-73.

Tatara, K. 1981. Relation between the primary production and the commercial fishery production in the fishing ground utilization of the primary production by the boat fishery (in Japanese with English abstract). Bulletin Nansen Regional Fisheries Research Laboratorium 13:111-133.

Tewfik, A., J. B. Rasmussen, and K. S. McCann. 2005. Anthropogenic enrichment alters a marine benthic food web. Ecology 86:2726-2736.

van de Kam, J., B. Ens, T. Piersma, and L. Zwarts. 2004. Shorebirds: an illustrated behavioural ecology. KNNV Publishers, Utrecht, The Netherlands.

van der Veer, H. W., R. Dapper, P. A. Henderson, A. S. Jung, C. J. Philippart, J. I. Witte, and A. F. Zuur. 2015. Changes over 50 years in fish fauna of a temperate coastal sea: Degradation of trophic structure and nursery function. Estuarine, Coastal and Shelf Science 155:156-166.

van Oevelen, D., K. Soetaert, J. J. Middelburg, P. M. J. Herman, L. Moodley, I. Hamels, T. Moens, and C. H. R. Heip. 2006. Carbon flows through a benthic food web: Integrating biomass, isotope and tracer data. Journal of Marine Research 64:453-482.

van Raaphorst, W., and H. W. van der Veer. 1990. The phosphorus budget of the Marsdiep tidal basin (Dutch Wadden Sea) in the period 1950-1985-importance of the exchange with the North-Sea. Hydrobiologia 195:21-38.

Van Straaten, L. M. J. U., and P. H. Kunnen. 1957. Accumulation of fine-grained sediments in the Dutch Wadden Sea. Geologie en Mijnbouw 19:329-354.

Vander Zanden, M. J., J. M. Casselman, and J. B. Rasmussen. 1999. Stable isotope evidence for the food web 
consequences of species invasions in lakes. Nature 401:464 467.

Verwey, J. 1952. On the ecology on the distribution of cockle and mussel in the Dutch Waddensea, their role in sedimentation and the source of their food supply. Archives Neerlandaises de Zoologie 10:171-239.

Wolff, W. J. 1983. Ecology of the Wadden Sea. Bakema, Rotterdam, The Netherlands.

Wolff, W. J. 2000. Causes of extirpations in the Wadden Sea, an estuarine area in the Netherlands. Conservation Biology $14: 876-885$
Zagwijn, W. H. 1986. Nederland in het Holoceen. Rijks Geologische Dienst, Haarlem, The Netherlands.

Zijlstra, J. 1972. On the importance of the Wadden Sea as a nursery area in relation to the conservation of the southern North Sea fishery resources. Symposia of the Zoological Society of London 29:233-258.

Zwarts, L., A. M. Blomert, and J. H. Wanink. 1992. Annual and season variation in the food supply harvestable by knot Calidris canutus staging in the Wadden Sea in late summer. Marine Ecology Progress Series 83:129139.

\section{SUPPORTING INFORMATION}

Additional supporting information may be found in the online version of this article at http://onlinelibrary.wiley.com/doi/ 10.1002/ecy.1837/suppinfo

\section{DAta ACCEssibility}

The data are deposited in Figshare at https://doi.org/10.6084/m9.figshare.4765087.v1 